Moreover, the innovative Strategic Partnership between Latvian and Ukrainian VET professionals demonstrates their volition tobalance and strengthen correlation between the European VET education and global labour market.

\title{
References:
}

1. Blanco, L. F. (12 Feb. 2016). The functions of 'strategic partnership' in European Union foreign policy discourse, Journal Cambridge Review of International Affairs, 29(1). 36-54. Reterieved from: https://www.tandfonline.com/doi/ref/10.1080/09557571.2015.1126055?scroll=top

2. Czechowska, L. (January 2013) The concept of strategic partnership as an input in the modern alliance theory, The Copernicus Journal of Political Studies 2013, No. 2 (4). 36-51. Retrieved from: https://www.researchgate.net/publication/264257630_The_concept_of_strategic_partnership_as_an_ input_in_the_modern_alliance_theory

3. Strategic Partnerships in the field of education, training and youth. Retrieved from: https://ec.europa.eu/programmes/erasmus-plus/programme-guide/part-b/three-key-actions/keyaction-2/strategic-partnerships-field-education-training-youth_en

\section{THE PERFORMING AND PROFESSIONAL COMPETENCE OF THE FUTURE SPECIALISTS IN MUSICAL ART}

\author{
Oksana Tsuranova ${ }^{1}$ \\ Olena Pohoda ${ }^{2}$
}

DOI: https://doi.org/10.30525/978-9934-588-11-2_54

The modern requirements for training specialists require a new approach to the content of education, an update of the educational repertoire, especially by means of adding the compositions of domestic composers, ancient and modern masters, as well as the change of the approach to teaching the piano in accordance with the requirements of the modern education.

The future teacher of musical art needs to be able to play the piano freely enough to influence the upbringing and spiritual development of the younger generation through the performance of compositions on the instrument by the means of musical art. It is in the education of a harmonious person that the purpose and content of the profession of the teacher lies.

The purpose of the work is to identify some ways of forming the performing and professional competence of the future specialists in musical art. In this sense, some provisions regarding the complex of elements of musical-creative, musical-analytical, general-pedagogical and psychological context have been considered.

\footnotetext{
${ }^{1}$ Public Institution «Kharkiv Humanitarian Pedagogical Academy» Kharkiv Regional Council, Ukraine

${ }^{2}$ Public Institution «Kharkiv Humanitarian Pedagogical Academy»

Kharkiv Regional Council, Ukraine
} 
The determination and scientific substantiation of directions and methods of the effective development of independence and performing-professional competence in music-pedagogical practice were made in the works by A. Alekseyev, L. Barenboim, and G. Tsypin. The musicians-pedagogues L. Archazhnikova, T. Vorobkevych, Gh. Padalka, O. Rostovsky, while developing the multifaceted nature of the profession of the future teacher of musical art, define a wide range of specialists' training by actualizing the development of their independent creative and cognitive activity.

The pedagogical abilities of the future musician-teacher are a complicated complex of different elements of musical-creative, musical-analytical, general-pedagogical and psychological content. Many of the most difficult tasks, the huge number of different music compositions being studied - this is the specificity of working in the piano class. During these lessons one forms views, musical taste, professional skills of the future specialist, his/her creative activity increases, intelligence develops, the love for music is being cultivated [1].

The independent practical work of students has certain didactic goals: to deepen and expand, to systematize and consolidate the knowledge acquired during the classroom lessons; to develop the abilities, skills of independent performing mental work; to promote interest and curiosity in professionally oriented activities; to develop independent thinking; to form volitional traits of character [2]. The achievement of these goals is possible if students have a formed need to acquire performing and professional competence.

The most important for the future specialist of musical art is the activation of cognitive activity and the ability to disclose the content of a musical composition, and for this he/she needs to possess a complex of professional skills: a certain sound production, a cantilena play, a conscious phrasing, a literate pedal use, a developed polyphonic thinking; a competent and logical interpretation of the texture of a musical composition, an apprehension of the composition as a whole and so on [3]. Mastering the skills of performing musical compositions on the piano is not the goal, but only an integral part of the comprehensive training of the future specialist. The profession requires universal knowledge, skills and abilities of a special kind.

In the present context, the main task of the educational and training process is to create the conditions for comprehensive development of a personality and the formation of students' performing and professional competence. One of the main tasks of the piano training is connected with the development of the ability to understand and reproduce the content of a musical composition [4]. Acquiring the experience of working with the note texts of musical compositions of various figurative content, students master the appropriate means of musical expression, feel the logical connection of musical elements, and master the performing techniques, while acquiring certain performing and professional competence [5].

The basic music-didactic principles form the foundation of the developmental learning in the piano class: the expansion of the repertoire for enriching the professional level and experience of the student, increasing the amount of material used in the classes (from simple to more complex); the intensification of the 
educational and training process and the development of the student's creative thinking by accelerating the rate of the mastering of a certain part of the educational material (the so-called sketchy study of a musical composition); the peculiarity of the role of the process of reading from the sheet, as a type of the educational activity [6]. In the course of acquiring performing skills, the basic didactic principles of the developmental learning - mastering the maximum of information in the minimum of time - stand out.

The implementation of these provisions into the practice of piano training will help to enhance the students' creative and cognitive autonomy and to form the basis of performing and professional competence [7].

Therefore, teaching the musical disciplines is focused on the formation of highly cultural, widely educated teachers of musical art at preschool and general secondary education institutions, who have the basic principles of performing and professional competence, acquire the perfect instrumental and performing qualities, are capable of revealing the artistic content of musical compositions by means of the corresponding means of musical expression, have the necessary skills to independently work on musical-theoretical material and certain educational and research achievements, are prepared for a thorough mastery of the peculiarities of performance, regularities of designing and application of musical material in the practical musical-pedagogical and musical-educational activities.

\section{References:}

1. Alekseev, A.D. (1978). Metodika obucheniya igre na fortepiano [Methods of learning to play the piano]. Moskva : Muzyka. (in Russian)

2. Barenboym, L. (1973). Put' k muzitsirovaniyu. Issledovanie [The way to music]. Leningrad : Sovetskiy kompozitor. (in Russian)

3. Padalka, Gh. (2008). Pedaghoghika mystectva. Teorija i metodyka vykladannja mystecjkykh dyscyplin [Art Pedagogy. Theory and methodology of teaching art disciplines]. Kyiv : Osvita Ukrajiny. (in Ukrainian)

4. Archazhnikova, L.G. (1984). Professiya - uchitel' muzyki [Profession - music teacher]. Moskva : Prosveshchenie. (in Russian)

5. Tsypin, G.M. (1984). Obuchenie igre na fortepiano [Learning to play the piano]. Moskva : Prosveshchenie. (in Russian)

6. Vorobkevych, T. (2001). Metodyka vykladannja ghry na fortepiano [Methods of teaching piano]. Ljviv : LDMA. (in Ukrainian)

7. Rostovsjkyj, O. (2001). Metodyka vykladannja muzyky [Methods of teaching music]. Ternopilj : Navchaljna knygha. (in Ukrainian) 